\title{
CARNITINE EFFECTS ON SERUM AND PANCREAS INFLAMMATORY RESPONSE IN DIABETIC RATS
}

\author{
Y. MASOUMI-ARDAKANI ${ }^{1}$, H. FALLAH ${ }^{2}$, B. SHAHOUZEHI ${ }^{\circledR}$ \\ ${ }^{1}$ Physiology Research Center, Institute of Basic and Clinical Physiology \\ Sciences, Kerman University of Medical Sciences, Kerman, Iran; \\ ${ }^{2}$ Student Research Committee, School of Medicine, \\ Kerman University of Medical Sciences, Kerman, Iran; \\ ${ }^{3}$ Cardiovascular Research Center, Institute of Basic and Clinical Physiology \\ Sciences, Kerman University of Medical Sciences, Kerman, Iran; \\ 凹e-mail: bshahouzehi@yahoo.com,bshahouzehi@gmail.com
}

Received: 08 May 2019; Accepted: 18 October 2019

Diabetes is a group of disorders characterized by elevated blood glucose and insulin secretion defect. Previous studies have reported L-carnitine beneficial and hypoglycemic effects in diabetic models. L-carnitine anti-inflammatory properties in diabetes were not assessed perfectly, and there is a lack of information about this matter. Therefore, we designed this study and evaluated L-carnitine different doses supplementation on pro-inflammatory cytokines in STZ-induced diabetic rats' pancreas and serum. We selected 48 male rats $(200 \pm 10 \mathrm{~g})$ and randomly divided them into six groups $(n=8)$. Group 1, control; group 2, Diabetic control (DC); groups 3-6, STZ-induced diabetic rats which received L-carnitine different doses as follow; 300, 200, 100 and $50 \mathrm{mg} / \mathrm{kg} /$ day by intraperitoneal injection for 5 weeks. When the study ended, serum and pancreas samples were collected and cytokines levels were measured by specific ELISA kits. Our results showed that in diabetic rats, pro-inflammatory cytokines levels were elevated. Two L-carnitine doses 300 and $200 \mathrm{mg} /$ $\mathrm{kg} /$ day showed beneficial effects and $300 \mathrm{mg} / \mathrm{kg} /$ day showed more effective and significant effects than other doses. The $300 \mathrm{mg} / \mathrm{kg}$ significantly reduced IL-1B and IL-6 levels in pancreas and serum. Our data proved the protective effects of intraperitoneal L-carnitine administration against diabetes and inflammation in diabetic rats. Indeed, L-carnitine long term supplementation through the intraperitoneal injection can be considered as a good and safe therapeutic strategy in diabetes.

Ke ywo rds: L-carnitine, $I L-1 \beta, I L-6, T N F-\alpha$, diabetic rat.

$\mathrm{D}$ iabetes is a chronic and endocrine disorder. It was estimated that it affects about 438 million people by 2030worldwide [1]. There are oxidative stress and inflammation in diabetic patients, along with diabetes development and progress [2-5]. There are two main categories' of diabetes, and there is a different mechanism behind each one. Type 1 diabetes (T1D) considered as an autoimmune disease with almost no insulin secretion and type 2 diabetes (T2D) which is caused by insulin resistance [6]. In fact, inflammation can be blamed for being involved in both. There are studies which confirm the participation of inflammation in diabetes pathophysiology [7]. In T1D, autoimmune antibodies attack pancreas and damage $\beta$-cell, on the other hands, in T2D, there is chronic hyperglycemia and lipotoxicity, which result in elevation of inflammatory cytokines [8-10].

Cytokines are small glycoproteins which are involved in inflammation and immunity. Two important cytokines in the inflammatory response are interleukin-1 $\beta$ (IL-1 $\beta$ ) and tumor necrosis factor- $\alpha$ $(\mathrm{TNF}-\alpha)$ [11]. Inflammations have indisputable effects on $\beta$-cell insulin secretion and there are shared of evidence which showed that inflammation and pro-inflammatory cytokines are involved in the

(C) 2019 Masoumi-Ardakani Y. et al. This is an open-access article distributed under the terms of the Creative Commons Attribution License, which permits unrestricted use, distribution, and reproduction in any medium, provided the original author and source are credited. 
$\beta$-cell inflammatory process, oxidative stress and dysfunction $[12,13]$. Pancreatic $\beta$-cell responds to long exposure to FFA and hyperglycemia by promoting the expression of inflammatory cytokines. FFAs are able to promote IL-1 $\beta$ and IL-6 secretion and long exposure of pancreatic $\beta$-cell to these inflammatory agents lead to free radical activation and $\beta$-cell apoptosis $[2,8]$. It seems that IL-1 is highly involved in the $\beta$-cell inflammatory process. Cytokines from other sources such as immune cells and adipose tissue also are contributed to the $\beta$-cell inflammatory process in diabetes. TNF- $\alpha$ is one of these cytokines which affects lipid and carbohydrate metabolism [7]. It has been reported that circulating IL-6 levels is elevated in subjects with insulin resistance and also it can be considered as a predictor of diabetes development [7].

Carnitine (3-hydroxy-4-N-trimethylaminobutyrate) is an endogenous nonessential amino acid. L-carnitine is the active form of carnitine which is synthesized from amino acids methionine and lysine in liver and kidney; also, it can be obtained from the diet [14]. Because L-carnitine has an important responsibility in intermediary metabolism, its levels in tissue and plasma is regulated at a restricted range [3]. Several studies investigated antidiabetic effects of L-carnitine and showed its hypoglycemic effects in diabetic rats [3,15-17]. L-carnitine is able to undertake inflammation and its anti-inflammatory properties were reported previously $[18,19]$. In a case-control study, Lee and colleagues investigated L-carnitine anti-inflammatory properties of L-carnitine in CAD patients. They found that L-carnitine administration $(1 \mathrm{gr} / \mathrm{d})$ reduced inflammation in patients with CAD after 12 weeks [20]. Also, there are investigations which have reported protective and beneficial effects of carnitine administration against pancreatic toxicity and pancreatitis in human studies as well as in animal models [21-23].

The route of L-carnitine administration to animal models was different (oral, intraperitoneal, subcutaneous, and intravenous). Indeed, L-carnitine quantity which used was different between previous researches. Also, there was no study which evaluated L-carnitine effects on pro-inflammatory cytokines in diabetic models. Duranay et al. and Calo and colleagues have reported anti-inflammatory properties of L-carnitine [18, 19]. Duranay et al. evaluated 3 times/weeks L-carnitine effects in hemodialysis patients, which significantly reduced CRP in these patients [18]. Calo et al. found that L-carnitine, in endothelial cell culture in presence of hydrogen peroxide, stimulates heme oxygenase-1 (HO-1) and NO synthase (HO-1 and NO synthase has anti-inflammatory, anti-oxidant and anti-proliferative properties) [19]. Therefore, we aimed to evaluate the effect of different doses of L-carnitine on blood glucose and pro-inflammatory cytokines (IL-1 $\beta$, IL-6, and TNF- $\alpha$ ) in serum and pancreas tissue of STZ-induced diabetic rats.

\section{Materials and Methods}

Materials. Streptozotocin (STZ; S0130), L-carnitine (C0283) were supplied from Sigma. IL-1 $\beta$ (BMS630), IL-6 (BMS625) and TNF- $\alpha$ (BMS622) ELISA kits were purchased from eBioscience Company.

Methods. All the animal experiments were performed in accordance with the requirements of the European Convention for the protection of vertebrate animals used for experimental and other scientific purposes (Strasbourg, 1986). L-carnitine was dissolved in PBS, pH 7.4, and introduced to diabetic rats by intraperitoneal injections at different doses. STZ was dissolved in citrate buffer $(\mathrm{pH} 4.5,0.1 \mathrm{~N})$ and administrated to animals by intraperitoneal injection. We purchased 48 male Wistar rats $(200 \pm 10 \mathrm{~g}$ weight) from Physiology Research Center Animal Care Center. After 7 days acclimatization to a new environment, animals were randomly divided into 6 groups $(n=8)$. Groups were prepared as follow: group 1, control (CTR) which received no treatment; group 2, diabetic control group (DC) received a single intraperitoneal injection of STZ $(50 \mathrm{mg} / \mathrm{kg})$ to induce diabetes; group 3-6, diabetic rats (diabetesinduced as group 2) which received different doses of L-carnitine $(300,200,100$ and $50 \mathrm{mg} / \mathrm{kg} /$ day L-carnitine by i.p. injection) for 5 weeks, respectively.

Diabetes was induced in fasted $(10 \mathrm{~h})$ rats by intraperitoneal injection of $50 \mathrm{mg} / \mathrm{kg}$ of STZ. Three days after STZ injection, the animal were fasted overnight $(10 \mathrm{~h})$ and the blood samples were collected from tail vein and fasting blood glucose (FBG) were measured by glucometer (Accu-Chek, Roche, Germany) and animals with FBG > 250 mg/dl were entered to the study as diabetic animals $[12,24]$. At the end of the study, the $10 \mathrm{~h}$ fasted animals, were decapitated under deep anesthesia and blood samples were collected and pancreas tissue was dissected and frozen immediately in liquid nitrogen and stored at $-80{ }^{\circ} \mathrm{C}$ until further examination [24]. 
Measurement of pro-inflammatory cytokines. Pancreas samples of animals were sonicated and homogenized by Ultrasonic Processor (Hielscher, $\mathrm{UP} 200 \mathrm{H}$ ) in cold PBS with $\mathrm{pH}=7.4$. The homogenized samples were centrifuged $15 \mathrm{~min}$ at $4{ }^{\circ} \mathrm{C}$ $(15000 \mathrm{rpm})$ and then the supernatants were collected and IL-1 $\beta$, IL- 6 and TNF- $\alpha$ were quantified by ELISA method [24, 25].

Measurement of IL-1 $\beta$, IL- 6 and TNF- $\alpha$ was performed by specific kits which are based on ELISA sandwich formation. In each kit, the first specific antibody is coated at ELISA wells and this antibody is dependent on which cytokine is going to be detected. After serum or supernatant loading into the wells and incubation, the next step is washing which followed by second antibody addition to the reaction mixture which results in ELISA sandwich formation and then yellow color generated after the addition of stop solution. Finally, the reaction color development in wells is measured at $450 \mathrm{~nm}$ by ELISA plate reader [25, 26].

Statistical analysis. All data are expressed as Mean \pm SEM. Data analysis was performed by one-way ANOVA test followed by post hoc Tukey's to compare mean differences between groups. The $P<0.05$ was considered as statistically significant.

\section{Results and Discussion}

The diabetic control group (STZ-induced diabetic rats) showed significant elevation of glucose, serum and pancreas values of IL-1 $\beta$ (Table, Fig. 1, A, Fig. 2, $A$ ), IL-6 (Fig. 1, $C$, Fig. 2, $C$ ), pancreas TNF- $\alpha$ $(P<0.001)$ (Fig. $1, B)$, serum TNF- $\alpha(P=0.004)$ (Fig. 2, B) compared to control group.

Administration of $300 \mathrm{mg} / \mathrm{kg} /$ day of L-carnitine significantly reduced serum glucose, pancreas IL-1 $\beta$ (Fig. $1, A$ ) and also serum IL-1 $\beta$ and IL-6 levels $(P<0.001)$ (Fig. $2, A$ and $C)$. Administration of $200 \mathrm{mg} / \mathrm{kg} /$ day of L-carnitine significantly reduced glucose levels $(P<0.001)$, serum IL-1 $\beta$ $(P=0.017)$ (Fig. 2, $A)$ and pancreas IL-1 $\beta$ and IL-6 values $(P<0.01)$ (Fig. $1, A$ and $C)$ compared to
DC group. Supplementation of $200 \mathrm{mg} / \mathrm{kg} / \mathrm{day}$ of L-carnitine was not as effective as $300 \mathrm{mg} / \mathrm{kg} /$ day of L-carnitine. Low doses of L-carnitine (50 and $100 \mathrm{mg} / \mathrm{kg} /$ day) did not show any significant effects.

Our results showed that L-carnitine i.p. administration has valuable effects which attenuated pro-inflammatory cytokines levels in pancreas and serum of STZ-induced diabetic rats. Also, we found that $300 \mathrm{mg} / \mathrm{kg} /$ day of L-carnitine is very effective compared to other doses we administrated in this study.

Intraperitoneal administration of $600 \mathrm{mg} / \mathrm{kg} /$ day of L-carnitine attenuated serum glucose, and lipid profile in a rat model of type 2 diabetes [27]. Previously, we showed that $600 \mathrm{mg} / \mathrm{kg} / \mathrm{day}$ of oral L-carnitine administration (5 weeks) reduced serum glucose and normalized insulin in STZ-induced diabetic rats [15]. Other studies also evaluated the therapeutic effects of L-carnitine in diabetic models [15, $27,28]$. We found that high doses of L-carnitine (200 and $300 \mathrm{mg} / \mathrm{kg} / \mathrm{day}$; i.p. administration) decreased serum glucose levels. L-carnitine glucose-lowering effects in diabetes is controversial. Several studies showed glucose-lowering effect upon L-carnitine administration but some other studies were not successful to show this hypoglycemic property of L-carnitine [15, 27, 29-32]. This controversy could be contributed to the route of L-carnitine administration in different studies. This is obvious that the studies in which L-carnitine was introduced by i.p. injections, they obtained more prominent and remarkable hypoglycemia compare to studies which administrated L-carnitine orally. Also, those studies used a lower dosage of L-carnitine compared to studies which administrated L-carnitine orally.

Inflammation is involved in apoptosis, dedifferentiation and malfunction of $\beta$-cell $[33,34]$. Chronic inflammation compromised $\beta$-cell insulin secretion and IL1 $\beta$, IL- 6 , TNF- $\alpha$ and interferons have shown potent deleterious effects on $\beta$-cells function [34]. In the case of reduced insulin secretion, it was reported that IL-1 $\beta$ showed strong det-

Anti-hyperglycemic effect of different doses of L-carnitine in diabetic rats' serum

\begin{tabular}{l|c|c|c|c|c|c}
\hline \multirow{2}{*}{ Concentration } & \multicolumn{6}{|c}{ Animal groups } \\
\cline { 2 - 7 } & CTR & DC & D+LCAR50 & D+LCAR100 & D+LCAR200 & D+LCAR300 \\
\hline Glucose, $\mathrm{mg} / \mathrm{dl}$ & $91.0 \pm 3.2^{\#}$ & $309.8 \pm 7.3^{*}$ & $283.8 \pm 10.1^{*}$ & $277.3 \pm 11.7^{*}$ & $230.0 \pm 9.3^{*, *}$ & $155.0 \pm 5.9^{*, *}$ \\
\hline
\end{tabular}

The data are expressed as mean \pm SEM; $P<0.05$ was considered as significant. *Statistically significant compared to control group; " statistically significant compared to diabetic group. Control (CTR), diabetic control (DC). 

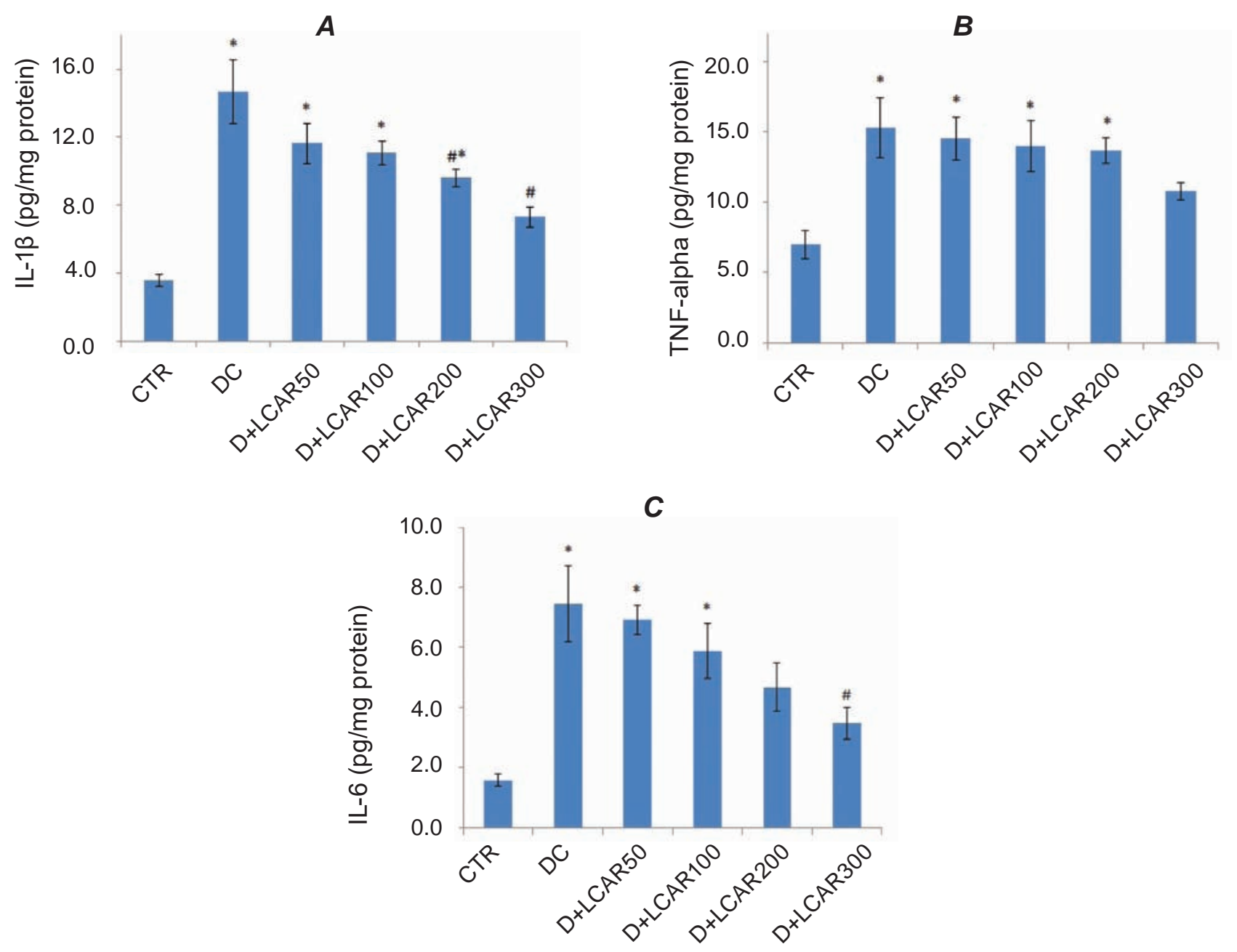

Fig. 1. Cytokines values in pancreas tissue measured by ELISA method in studied groups which were as follow; CTR group, untreated control; DC, Diabetic control group (received single dose of $50 \mathrm{mg} / \mathrm{kg}$ of STZ); group III-VI, diabetic groups which received different doses of L-carnitine (50, 100, 200 and $300 \mathrm{mg} / \mathrm{kg} / \mathrm{day})$ by i.p. injection for 5 weeks. Fig. A showed IL-1 B, Fig. B showed TNF- $\alpha$ and Fig. C showed IL-6 levels in each groups. $P<0.05$ was considered as significant. The data are expressed as Mean $\pm S E M$, * $*_{\text {statistically }}$ significant compared to CTR group, and ${ }^{\#}$ statistically significant compared to DC group

rimental effects than IL-6 and TNF- $\alpha$ [34]. This is well documented that pro-inflammatory cytokines such as IL-1 $\beta$, interferon- $\gamma($ IFN- $\gamma)$ and TNF- $\alpha$ are involved in diabetes especially T1D, and IL-1 $\beta$ result in $\beta$-cell death. IL-1 $\beta$ triggers the processes by NF$\kappa \mathrm{B}$ which final effect is apoptosis induction in pancreatic $\beta$-cell $[9,11]$. The L-carnitine effects on proinflammatory cytokines in serum and pancreas of STZ-induced diabetic models were not studied well enough. Two studies in 2006 by Duranay et al. and Calo et al., investigated anti-inflammatory effects of L-carnitine $[18,19]$. Duranay and colleagues have revealed CRP reducing effects of L-carnitine (3 times/ weeks) [18], on the other hands, Calo and colleagues in their in vitro study showed that L-carnitine antiinflammatory effects which was conducted through induction of HO-1 and NO synthase in endothelial cell culture [19]. Our finding revealed that confirmed pro-inflammatory cytokines levels were increased in STZ-induced diabetic rats compared to the control group. L-carnitine administration showed an important effect against pro-inflammatory cytokines elevation in diabetic rats. Hussein et al. showed that oral L-carnitine (300 mg/kg, 2 months) administration in high fructose diet rats normalized serum TNF- $\alpha$ and IL-6 levels [12]. Their findings are the same as our results which confirm L-carnitine effects which reduced IL- $1 \beta$, IL- 6 and TNF- $\alpha$ in serum and pan- 

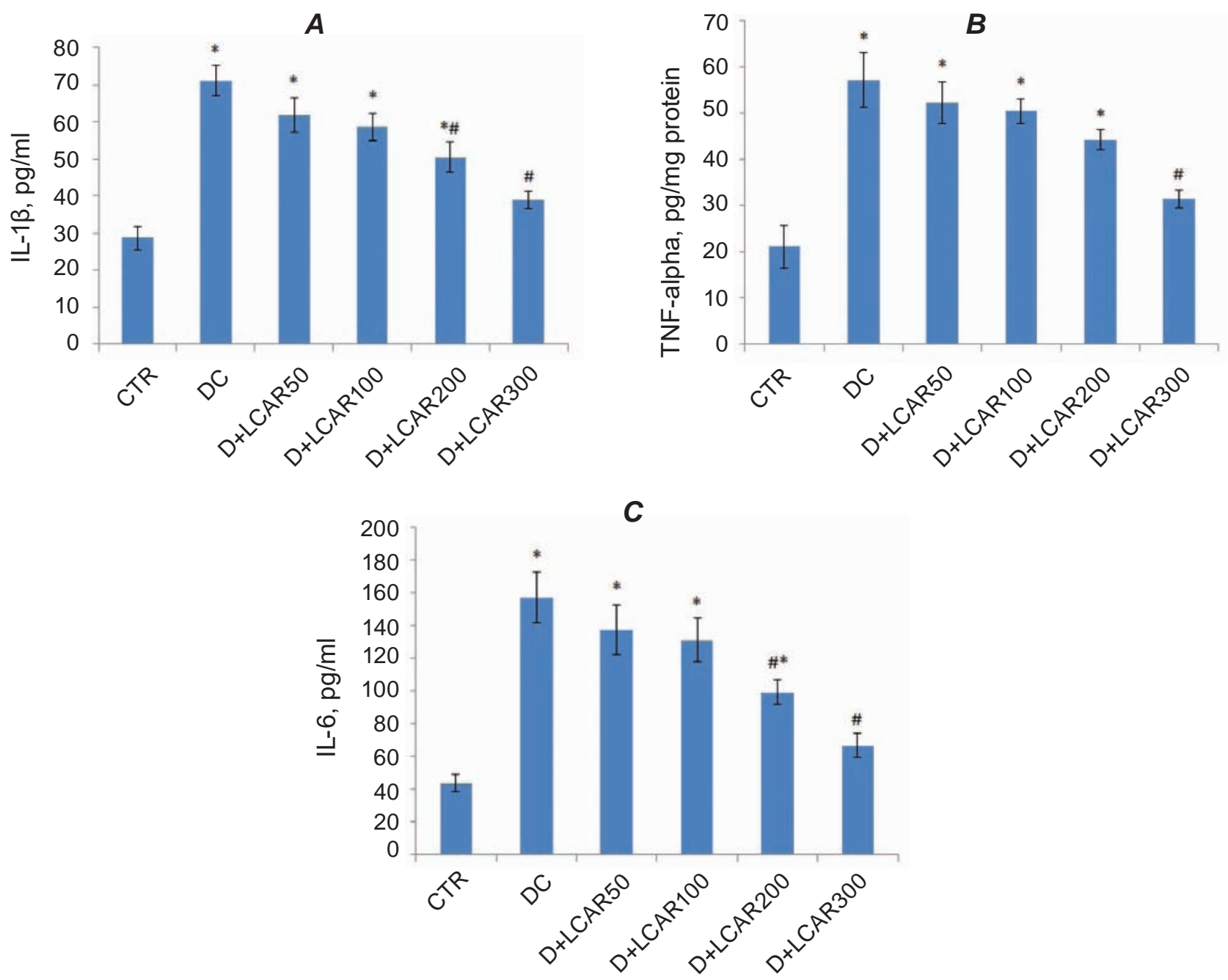

Fig. 2. Serum cytokines levels, measured by ELISA method in studied groups which were as follow; CTR group, untreated control; DC, Diabetic control group (received single dose of $50 \mathrm{mg} / \mathrm{kg}$ of STZ); group III-VI, diabetic groups which received different doses of L-carnitine (50, 100, 200 and $300 \mathrm{mg} / \mathrm{kg} /$ day) by i.p. injection for 5 weeks. Fig. A showed IL-1 $\beta$, Fig. B showed TNF- $\alpha$ and Fig. $\boldsymbol{C}$ showed IL-6 levels in each groups. $P<0.05$ was considered as significant. The data are expressed as Mean $\pm S E M$, *statistically significant compared to CTR group, and ${ }^{\#}$ statistically significant compared to DC group

creas tissue of diabetic rats. The $300 \mathrm{mg} / \mathrm{kg}$ of Lcarnitine is more effective than other doses which we administrated and $300 \mathrm{mg} / \mathrm{kg}$ of L-carnitine reducing effects on IL-1 $\beta$, IL- 6 is more than TNF- $\alpha$ compared to the diabetic control group. Zheng et al. showed that L-carnitine reduced pro-inflammatory cytokines expression and reduced increase of oxidative stress and apoptosis in STZ-induced diabetic nephropathy [35]. Laviano and colleagues described that L-carnitine administration to sarcoma-bearing rats caused beneficial effects and reduced inflammatory status by L-carnitine [36].

IL-1 $\beta$ has an important role in $\beta$-cell function and survival in human and rodents [9]. We found that 300 and $200 \mathrm{mg} / \mathrm{kg} \mathrm{L-carnitine} \mathrm{reduced} \mathrm{serum}$ and pancreas IL-1 $\beta$ levels. Therefore, it seems that attenuation of IL-1 $\beta$ levels can be considered as an important way by which L-carnitine exerts its beneficial effects in diabetic rats. TNF- $\alpha$ is an important pro-inflammatory cytokine which affects the metabolism of lipid and glucose. Also, it was reported that TNF- $\alpha$ is related to insulin resistance. TNF- $\alpha$ increases FFA and attenuates insulin signaling, it also affects insulin secretion and signaling [7]. These reports direct us to the idea that L-carnitine reduces insulin resistance state in diabetes and exerts insulin sensitizing effects through reducing TNF- $\alpha$ level. On the other hands, it has been reported that IL-6 
is elevated along with insulin resistance. Also, elevated serum IL-1 and IL-6 levels are contributed to diabetes mellitus occurrence[7]. L-carnitine attenuates serum IL-1 and IL-6 levels by reducing glucose and lipid toxicity in serum and pancreas and also by the improvement of anti-oxidant states, therefore it reduces pro-inflammatory cytokines and inflammation in diabetic models.

Conclusion. L-carnitine anti-oxidant and hypoglycemic effects in diabetic models confirm its protective effects in diabetic models. Adiponectin and AMPK are considered as insulin-sensitizing proteins which mimic insulin effects in the body. In our previous study, we found that L-carnitine supplementation increased AMPK expression and serum levels of adiponectin, therefore, it seems that L-carnitine hypoglycemic properties in this model which lost their almost $90 \%$ of islet beta-cells was contributed to indirect insulin sensitizing effects of L-carnitine. On the other hands, L-carnitine increases lipid beta-oxidation and reduces lipid levels in cells and probably promotes insulin effectiveness. These protective effects maintain homeostasis and protect tissue and organs from more injuries and finally, it can lower inflammatory response in diabetes. Also, L-carnitine i.p. administration is more effective than oral administration and its dose of administration is important to see the best action of L-carnitine in animal models. On the other hands, the duration of the study is also important. The longer the treatment lasts the more effective L-carnitine function we can observe.

Acknowledgements. This research was financially supported by Kerman Medical University Research Council and Physiology Research Center.

Conflict of interest. Authors have completed the Unified Conflicts of Interest form at http://ukrbiochemjournal.org/wp-content/uploads/2018/12/ coi_disclosure.pdf and declare no conflict of interest.

\section{ВПЛИВ КАРНІТИНУ НА ЗАПАЛЬНУ РЕАКЦЮЮ В СИРОВАТЦІ КРОВІ І ПІДШЛУ НКОВІЙ ЗАЛОЗІ ДІАБЕТИЧНИХ ЩУРІВ}

\author{
Y. Masoumi-Ardakani' ${ }^{1}$ H. Fallah ${ }^{2}$, \\ B. Shahouzehi ${ }^{3 凶}$
}

${ }^{1}$ Physiology Research Center, Institute of Basic and Clinical Physiology Sciences, Kerman

University of Medical Sciences, Kerman, Iran; ${ }^{2}$ Student Research Committee, School of Medicine,

Kerman University of Medical Sciences, Kerman, Iran; ${ }^{3}$ Cardiovascular Research Center, Institute of

Basic and Clinical Physiology Sciences, Kerman University of Medical Sciences, Kerman, Iran; 凶e-mail: bshahouzehi@yahoo.com, bshahouzehi@gmail.com

Діабет належить до захворювань, які характеризуються підвищеним рівнем глюкози в крові і порушенням секреції інсуліну. У попередніх дослідженнях на діабетичних моделях було виявлено, що L-карнітин виявляє гіпоглікемічний ефект. Однак, протизапальні властивості L-карнітину за діабету вивчені недостатньо. Метою дослідження було оцінити ефект різних доз L-карнітину на прозапальні цитокіни в підшлунковій залозі і сироватці крові в щурів зі стрептозоциніндукованим діабетом. Було відібрано 48 щурів-самців $(200 \pm 10$ г) і розділено випадковим чином на шість груп $(n=8)$. Група 1 - контрольна група; 2 - діабетичний контроль (ДК); групи 3-6 - щури зі стрептозоциніндукованим діабетом, яким вводили L-карнітин в різних дозах: 300, 200, 100 і 50 мг/кг на добу шляхом інтраперитонеальних ін'єкцій протягом 5 тижнів. Після цього збирали зразки сироватки крові і підшлункової залози і визначали рівень цитокінів за допомогою наборів ELISA. Виявлено, що у діабетичних щурів рівень прозапальних цитокінів був підвищений. Дві дози L-карнітину 300 i 200 мг/кг на добу показали 
позитивні ефекти, при цьому ефект від введення L-карнітину в дозі 300 мг/кг на добу був значнішим. L-карнітин у дозі 300 мг/кг на добу істотно знижував вміст IL-1 $\beta$ і IL-6 у підшлунковій залозі і сироватці крові. Одержані результати підтвердили захисний ефект інтраперитонеально введеного L-карнітину у разі запалення в діабетичних щурів. Отже, введення L-карнітину протягом тривалого часу можна розглядати як ефективну і безпечну терапевтичну стратегію за діабету.

К л ю ч о в і с л о в а: L-карнітин, IL-1 $\beta$, IL6 , TNF- $\alpha$, діабетичні щури.

\section{References}

1. Deepthi B, Sowjanya K, Lidiya B,Bhargavi RS, Babu PS. A Modern Review of Diabetes Mellitus: An Annihilatory Metabolic Disorder. J In Silico In Vitro Pharmacol. 2017; 3: 1.

2. Asmat U, Abad K, Ismail K. Diabetes mellitus and oxidative stress-A concise review. Saudi Pharm J. 2016; 24(5): 547-553.

3. Bene J, Hadzsiev K, Melegh B. Role of carnitine and its derivatives in the development and management of type 2 diabetes. Nutr Diabetes. 2018; 8(1): 8.

4. Pollack RM, Donath MY, LeRoith D, LeibowitzG. Anti-inflammatory Agents in the Treatment of Diabetes and Its Vascular Complications. Diabetes Care. 2016; 39(Suppl 2): S244-S252.

5. Paul J. Role of Inflammation in Obesity and Diabetes. J Obes Metab. 2018; 1: 102.

6. Karalliedde J, Gnudi L. Diabetes mellitus, a complex and heterogeneous disease, and the role of insulin resistance as a determinant of diabetic kidney disease. Nephrol Dial Transplant. 2016; 31(2): 206-213.

7. Lontchi-Yimagou E, Sobngwi E, Matsha TE, Kengne AP. Diabetes mellitus and inflammation. Curr Diab Rep. 2013; 13(3): 435-444.

8. Cieślak M, Wojtczak A, Cieślak M. Role of proinflammatory cytokines of pancreatic islets and prospects of elaboration of new methods for the diabetes treatment. Acta Biochim Pol. 2015; 62(1): 15-21.

9. Cnop M, Welsh N, Jonas JC, Jörns A, Lenzen S, Eizirik DL. Mechanisms of pancreatic betacell death in type 1 and type 2 diabetes: many differences, few similarities. Diabetes. 2005; 54(Suppl 2): S97-S107.
10. Gerber PA, Rutter GA. The role of oxidative stress and hypoxia in pancreatic beta-cell dysfunction in diabetes mellitus. Antioxid Redox Signal. 2017; 26(10): 501-518.

11. Eizirik DL, Mandrup-Poulsen T. A choice of death--the signal-transduction of immunemediated beta-cell apoptosis. Diabetologia. 2001; 44(12): 2115-2133.

12. Hussein SA, Abd El-Hamid OM, Hemdan HS. Protective effect of L-carnitine on metabolic disorders, oxidative stress, antioxidant status and inflammation in a rat model of insulin resistance. Benha Vet Med J. 2013; 25(2): 99-112.

13. Acosta-Montaño P, García-González V. Effects of Dietary Fatty Acids in Pancreatic Beta Cell Metabolism, Implications in Homeostasis. Nutrients. 2018; 10(4). pii: E393.

14. D'Antona G, Nabavi SM, Micheletti P, Di Lorenzo A, Aquilani R, Nisoli E, Rondanelli M, Daglia M. Creatine, L-carnitine, and $\omega 3$ polyunsaturated fatty acid supplementation from healthy to diseased skeletal muscle. Biomed Res Int. 2014; 2014: 613890.

15. Shahouzehi B, Barkhordari K, Aminizadeh S, Masoumi-Ardakani Y. Effect of L-carnitine administration on serum insulin and adiponectin levels, and AMPK, APPL1 and PPAR $\gamma$ gene expression in STZ-induced diabetic rat liver. Ukr Biochem J. 2017; 89(6): 48-55.

16. Abdel-Razek HA. Beneficial effect of L-carnitine on the neuromuscular performance in diabetic rats. Menoufia Med J. 2010; 23: 159-173.

17. Hadadinezhad S., Ghazaleh N, Razavi Z. Effects of L-carnitine on glycemic control and C-peptide levels in patients with type 2 diabetes mellitus. Turk Jem. 2008; 12(1): 1-3.

18. Duranay M, Akay H, Yilmaz FM, Senes M, Tekeli N, Yücel D. Effects of L-carnitine infusions on inflammatory and nutritional markers in haemodialysis patients. Nephrol Dial Transplant. 2006; 21(11): 3211-3214.

19. Calò LA, Pagnin E, Davis PA, Semplicini A, Nicolai R, Calvani M, Pessina AC. Antioxidant effect of L-carnitine and its short chain esters: relevance for the protection from oxidative stress related cardiovascular damage. Int J Cardiol. 2006; 107(1): 54-60.

20. Lee BJ, Lin JS, Lin YC, Lin PT. Antiinflammatory effects of L-carnitine supplementation (1000 mg/d) in coronary artery disease patients. Nutrition. 2015; 31(3): 475-479. 
21. Sadighara M, Joktaji JP, Hajhashemi V, Minaiyan M. Protective effects of coenzyme Q10 and L-carnitine against statin-induced pancreatic mitochondrial toxicity in rats. Res Pharm Sci. 2017; 12(6): 434-443.

22. Karakahya M, Gül M, Işık S, Aydın C, Yiğitcan B, Otan E, Orug T. The histopathologic effects of L-carnitine in sodium taurocholate induced severe pancreatitis model. Int Surg. 2016; 101(5-6): 241-248.

23. Xiang Y, Piao SG, Zou HB, Jin J, Fang MR, Lei DM, Gao BH, Yang CW, Li C. L-carnitine protects against cyclosporine-induced pancreatic and renal injury in rats. Transplant Proc. 2013; 45(8): 3127-3134.

24. Rezaei N, Mardanshahi T, Shafaroudi MM, Abedian S, Mohammadi H, Zare Z. Effects of L-carnitine on the follicle-stimulating hormone, luteinizing hormone, testosterone, and testicular tissue oxidative stress levels in streptozotocininduced diabetic rats. $J$ Evid Based Integr Med. 2018; 23: 2515690X18796053.

25. Shahouzehi B, Sepehri Gh, Sadeghiyan S, Masoumi-Ardakani Y. Ameliorative effects of Pistacia atlantica resin oil on experimentallyinduced skin burn in rat. Res $J$ Pharmacogn. 2019; 6(1): 29-34.

26. Shahouzehi B, Shabani M, Shahrokhi N, Sadeghiyan S, Masoumi-Ardakani Y. Effects of Pistacia atlantica resin oil on the level of VEGF, hydroxyproline, antioxidant and wound healing activity in STZ-induced diabetic rats. $U k r$ Biochem J. 2018; 90(1): 34-41.

27. Salmanoglu DS, Gurpinar T, Vural K, Ekerbicer N, Darıverenli E, Var A. Melatonin and L-carnitin improves endothelial disfunction and oxidative stress in Type 2 diabetic rats. Redox Biol. 2016; 8: 199-204.

28. Samir SM, Abbas AM, Safwat SM, Elserougy HG. Effect of L-carnitine on diabetesinduced changes of skeletal muscles in rats.
J Basic Clin Physiol Pharmacol. 2018; 29(1): 4759.

29. Rajasekar P, Kaviarasan S, Anuradha CV. L-carnitine administration prevents oxidative stress in high fructose-fed insulin resistant rats. Diabetologia Croatica. 2005; 34(1): 21-28.

30. Irat AM, Aktan F, Ozansoy G. Effects of L-carnitine treatment on oxidant/antioxidant state and vascular reactivity of streptozotocindiabetic rat aorta. J Pharm Pharmacol. 2003; 55(10): 1389-1395.

31. Patel J, Goyal R, Bhatt P. Beneficial effects of levo-carnitine on lipid metabolism and cardiac function in neonatal streptozotocin rat model of diabetes. Int J Diabetes Metabolism. 2008; 16: 29-34.

32. Bazotte RB, Lopes-Bertolini G. Effects of oral L-carnitine and DL-carnitine supplementation on alloxan-diabetic rats. Braz Arch Biol Technol. 2012; 55(1): 81-88.

33. Imai Y, Dobrian AD, Morris MA, Nadler JL. Islet inflammation: a unifying target for diabetes treatment? Trends Endocrinol Metab. 2013; 24(7): 351-360.

34. Nordmann TM, Dror E, Schulze F, Traub S, Berishvili E, Barbieux C, Böni-Schnetzler M, Donath MY. The Role of Inflammation in $\beta$-cell Dedifferentiation. Sci Rep. 2017; 7(1): 6285.

35. Zheng H, Piao S, Sun L, Zhao H, Jin J, Jin J, Yang C, Li C. Renoprotective effects of L-Carnitine in streptozotocin-induced diabetic nephropathy. Int J Clin Exp Med. 2018; 11(5): 4459-4469.

36. Laviano A, Molfino A, Seelaender M, Frascaria T, Bertini G, Ramaccini C, Bollea MR, Citro G, Rossi Fanelli F. Carnitine administration reduces cytokine levels, improves food intake, and ameliorates body composition in tumorbearing rats. Cancer Invest. 2011; 29(10): 696700. 